Original Artikel

Spizaetus: Jurnal Biologi dan Pendidikan Biologi

Volume 2 Nomor 3, Oktober 2021

PISSN: 2716-151X

eISSN: 2722-869X

\title{
Pengaruh Model Pembelajaran Kooperatif Tipe Numbered Head Together (NHT) dan Jigsaw Terhadap Keaktifan dan Hasil Belajar Kognitif Siswa Pada Materi Keanekaragaman Hayati Kelas X SMA N 2 Maumere
}

\author{
Lusia Katarina Nona Ertin', Yohanes Nong Bunga ${ }^{2 *}$, Rofinus Galis ${ }^{3}$ \\ ${ }^{1,2,3}$ Program Studi Pendidikan Biologi, Fakultas Keguruan dan Ilmu Pendidikan, Universitas Nusa Nipa, \\ Maumere, 86111, Indonesia \\ *email: Uma.Sandy910@gmail.com
}

\begin{abstract}
ABSTRAK
Penelitian ini bertujuan untuk mengetahui Pengaruh Model Pembelajaran Kooperatif Tipe Numbered Head Together (NHT) dan Jigsaw Terhadap Keaktifan dan Hasil Belajar Kognitif Siswa pada Materi Keanekaragaman Hayati Kelas X SMA N 2 Maumere. Penelitian ini dilatarbelakangi oleh rendahnya minat belajar siswa. Hasil observasi di SMA Negeri 2 Maumere diperoleh bahwa sebagian siswa kurang aktif dalam proses pembelajaran. Jenis penelitian ini adalah penelitian kuantitatif. Rancangan penelitian yang digunakan adalah Quasi Eksperimental Design dengan bentuk desain berupa Pretest-Posttest Control Group Design. Populasi pada penelitian ini, yaitu siswa kelas X SMA Negeri 2 Maumere tahun pelajaran 2020/2021. Sampel dalam penelitian ini, yaitu siswa kelas XIPA ${ }^{1}$ dan kelas XIPA ${ }^{2}$ SMA Negeri 2 Maumere. Pengambilan sampel menggunakan teknik Simple Random Sampling. Hasil penelitian menunjukkan bahwa model pembelajaran kooperatif tipe Numbered Head Together (NHT) dapat meningkatkan keaktifan siswa. Hal ini dibuktikan dengan rata-rata persentase keaktifan siswa sebesar 78,55\%. Model pembelajaran kooperatif tipe Jigsaw dapat meningkatkan keaktifan siswa dengan ratarata persentase keaktifan sebesar 73,55\%. Model pembelajaran kooperatif tipe Numbered Head Together (NHT) dapat meningkatkan hasil belajar kognitif dengan nilai rata-rata Posttest sebesar 74,80\%. Model pembelajaran kooperatif tipe Jigsaw dapat meningkatkan hasil belajar kognitif siswa dengan nilai ratarata Posttest sebesar 65,96\%. Berdasarkan hal tersebut dapat disimpulkan bahwa model pembelajaran kooperatif tipe Numbered Head Together (NHT) dan Jigsaw berpengaruh secara signifikan terhadap keaktifan dan hasil belajar kognitif siswa pada materi Keanekaragaman Hayati Kelas X SMA N 2 Maumere.
\end{abstract}

Kata Kunci: Hasil Belajar Kognitif; Jigsaw; Keaktifan; Numbered Head Together 


\section{PENDAHULUAN}

Indonesia merupakan salah satu Negara di dunia yang sedang mengembangkan sistem pendidikan menuju lebih baik. Saat ini sistem pendidikan di Indonesia menggunakan kurikulum 2013 yang tidak hanya berorientasi terhadap hasil dan materi kependidikan melainkan juga memperhatikan proses. Pada proses pembelajaran, kurikulum 2013 menggunakan pendekatan ilmiah (scientific approach). Oleh karena itu, diharapkan proses transfer ilmu dan pengetahuan di sekolah dapat ditingkatkan agar kualitas keaktifan dan hasil pembelajaran dapat memenuhi tujuan yang telah ditetapkan (Sari dkk. 2017).

Pembelajaran IPA diharapkan tidak hanya memberikan kemampuan terhadap peserta didik untuk menyelesaikan soal, tetapi juga untuk melatih agar peserta didik mampu berpikir kritis, logis dan sikap ilmiah lainnya. Mata pelajaran biologi merupakan salah satu bagian mata pelajaran IPA wajib di Sekolah Menengah Atas (SMA). Lufri (2009) mengatakan bahwa pembelajaran dalam bidang biologi akan menarik bila pembelajaran tersebut mampu menggerakan atau mengaktifkan daya pikir dan aktivitas peserta didik.

Pembelajaran biologi cenderung monoton dan kurang menarik jika peserta didik hanya menerima penjelasan materi dari guru. Hasil observasi di SMA Negeri 2 Maumere diperoleh bahwa dalam pembelajaran, peserta didik selalu aktif atau sering memberikan pertanyaan adalah peserta didik yang mempunyai kemampuan tinggi sedangkan peserta didik yang mempunyai kemampuan sedang dan lemah cenderung bersikap pasif dan kurang merespon pertanyaan-pertanyaan yang diberikan oleh guru.

Hal ini mengakibatkan kesenjangan antara peserta didik semakin tinggi. Mulyasa (2002), pembelajaran dikatakan berhasil dan berkualitas apabila seluruhnya atau setidak-tidaknya sebagian besar peserta didik terlibat secara aktif, baik fisik, mental maupun sosial dalam pembelajaran. Permasalahan di atas akan berdampak pada rendahnya hasil belajar kognitif peserta didik. Untuk mengatasi hal tersebut perlu adanya variasi model pembelajaran dan penggunaan media pembelajaran yang menyenangkan. Lie (2002), menyatakan bahwa salah satu model pembelajaran yang dapat mengaktifkan siswa adalah model pembelajaran kooperatif.

Model pembelajaran kooperatif yang mendukung agar peserta didik berperan aktif dan bekerja sama dalam proses pembelajaran diantaranya model pembelajaran kooperatif tipe NHT dan Jigsaw. Silalahi dan Hasruddin (2016), menyatakan bahwa model pembelajaran kooperatif tipe NHT merupakan pembelajaran dengan sistem penomoran dan menempatkan peserta didik dalam kelompok-kelompok kecil untuk berdiskusi dan menelaah materi yang tercakup dalam suatu pelajaran. Model pembelajaran NHT, menginginkan satu peserta didik yang mewakili kelompoknya tanpa menginformasikan terdahulu kepada kelompok tersebut siapa yang akan menjadi wakilnya, kondisi ini mampu meningkatkan tanggung jawab individu dalam kelompok. Semua anggota kelompok harus menguasai materi pembelajaran, karena memiliki peluang yang sama untuk dipanggil oleh guru.

Model pembelajaran kooperatif tipe Jigsaw merupakan suatu model pembelajaran yang mendukung agar peserta didik berperan aktif dan bekerja sama dalam proses pembelajaran. Anggota kelompok bersifat heterogen dan bekerja sama saling membutuhkan yang positif dan bertanggung jawab ketuntasan bagian materi yang sudah tuntas dipelajari siswa kemudian disajikan kepada kelompok asal. Model pembelajaran kooperatif tipe Jigsaw merupakan salah satu model pembelajaran yang menekankan kepada kerja sama antar anggota kelompok. Rusman (2012), mengatakan bahwa dalam kegiatan 
pembelajaran model Jigsaw siswa bekerja sama saling ketergantungan positif dan bertanggung jawab secara mandiri.

Penelitian berkaitan dengan penerapan model kegiatan pembelajaran sudah dilakukan. Marning dan Lucking (1991), menyimpulkan bahwa siswa yang diajar dengan metode Jigsaw menjadi lebih menyukai teman-temannya dalam satu kelompok belajar dibanding dengan kesukaan mereka terhadap teman-temannya satu kelas yang bukan anggota kelompok belajarnya. Utami, $d k k$ (2017), menjelaskan bahwa hasil belajar dan aktivitas belajar antara kelas eksperimen dan kelas kontrol menunjukan

\section{METODE}

Penelitian ini telah dilakukan di SMA Negeri 2 Maumere, Kecamatan Alok, Kabupaten Sikka, Propinsi Nusa Tenggara Timur. Penelitian ini dilaksanakan pada tanggal 31 Agustus 2020 sampai 19 September 2020 dengan materi keanekaragaman hayati.

Jenis penelitian ini adalah penelitian kuantitatif. Rancangan penelitian yang digunakan adalah Quasi Eksperimental Design dengan bentuk desain berupa Pretest-Posttest Control Group Design.

Penelitian ini menggunakan dua kelas eksperimen. Desain dalam penelitian ini adalah kelas eksperimen I maupun kelas eksperimen II diberikan tes awal (pretest) dan tes akhir (posttest). Kelas eksperimen I adalah kelas X IPA $^{1}$ dengan menggunakan model pembelajaran kooperatif tipe Numbered Head Together (NHT) dan kelas eksperimen II adalah kelas X IPA ${ }^{2}$ dengan menggunakan model pembelajaran kooperatif tipe Jigsaw.

Populasi pada penelitian ini, yaitu seluruh siswa kelas X SMA Negeri 2 Maumere tahun pelajaran 2020/2021.

Sampel dalam penelitian ini menggunakan teknik Simple Random Sampling. adanya perbedaan. Rauf, $d k k$ (2017), menyatakan bahwa dengan menerapkan model NHT dapat memberikan pengaruh terhadap motivasi belajar siswa. Meskipun guru biologi di SMA Negeri 2 Maumere sudah berpengalaman dalam pengajaran dan bisa mengkondisikan siswa agar siswa terlibat aktif dalam pembelajaran tetapi pengamatan saya selama PPL saya belum menemukan guru biologi menerapkan model pembelajaran bervariasi. Penelitian ini dipandang perlu untuk mengetahui dampak dari penerapan model pembelajaran terhadap keaktifan dan hasil belajar kognitif siswa.

Dikatakan simpel (sederhana) karena pengambilan anggota sampel dari populasi dilakukan secara acak tanpa memperhatikan strata yang ada dalam populasi, Sugiyono (2016). Sampel yang diambil dalam penelitian yaitu kelas X IPA I sebagai kelas eksperimen 1 dan Kelas X IPA II sebagai kelas eksperimen 2. Jumlah sampel yang diambil adalah 52 siswa.

Jenis instrumen penelitian ini berupa instrumen tes dan instrumen non tes. Instrumen tes digunakan untuk mengukur peningkatan hasil belajar kognitif. Instrumen tes yang digunakan dalam penelitian ini berupa soal-soal pilihan ganda. Sedangkan instrumen non tes dalam penelitian ini berupa lembar observasi. Lembar observasi digunakan untuk mengukur keaktifan siswa. 


\section{HASIL DAN PEMBAHASAN}

a. Penerapan Model Pengaruh

Pembelajaran Kooperatif tipe Numbered

Head Together (NHT) Terhadap

Keaktifan Siswa

Penilaian keaktifan siswa dilakukan

setiap pertemuan kegiatan pembelajaran pada kelas eksperimen I. Penilaian ini bertujuan untuk mengetahui keaktifan siswa dalam mengikuti kegiatan pembelajaran. Keaktifan siswa diukur dengan menggunakan lembar observasi. Hasil penilaian keaktifan siswa dapat dilihat pada gambar berikut.

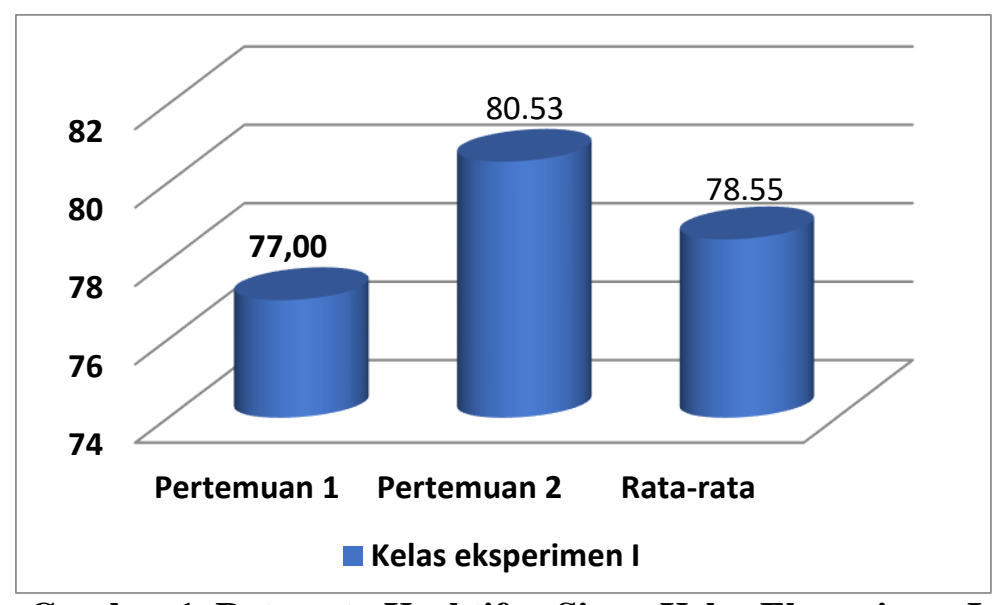

Gambar 1. Rata-rata Keaktifan Siswa Kelas Eksperimen I

Berdasarkan gambar 1 hasil observasi keaktifan siswa pada kelas eksperimen I menggunakan model pembelajaran kooperatif tipe NHT mengalami peningkatan. Hal ini dapat dilihat dari perolehan persentase keaktifan siswa pada setiap pertemuan yaitu pada pertemuan pertama memperoleh persentase sebesar $77.00 \%$ dan pertemuan kedua memperoleh persentase sebesar $80.53 \%$ dengan rata-rata persentase sebesar $78.55 \%$. Hasil perolehan persentase antara pertemuan pertama dan kedua pada kelas eksperimen I dengan menggunakan model pembelajaran kooperatif tipe NHT menunjukan adanya perbedaan. Hal tersebut dapat dikatakan bahwa adanya pengaruh yang signifikan antara penggunaan model pembelajaran kooperatif tipe NHT terhadap keaktifan siswa. Penelitian terdahulu terkait penggunaan model pembelajaran kooperatif tipe Number Head Together (NHT) salah satunya dari Rahayu (2018) menunjukkan bahwa terjadinya peningkatan keaktifan siswa dengan pemakaian model pembelajaran Number Head Togeher (NHT) secara signifikan yaitu sebesar $89,3 \%$ pada mata pelajaran akuntansi.

\section{b. Pengaruh Penerapan Model Pembelajaran Kooperatif tipe Jigsaw Terhadap Keaktifan Siswa}

Penilaian keaktifan siswa dilakukan setiap pertemuan kegiatan pembelajaran pada kelas eksperimen II. Penilaian ini bertujuan untuk mengetahui keaktifan siswa dalam mengikuti kegiatan pembelajaran. Keaktifan siswa diukur dengan menggunakan lembar observasi. Hasil penilaian keaktifan siswa dapat dilihat pada gambar berikut. 


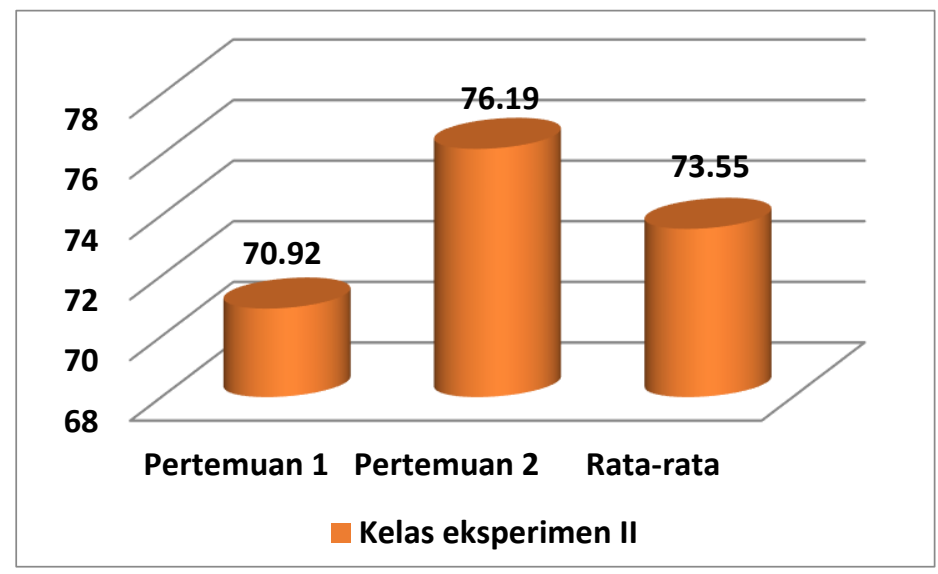

Gambar 2. Rata-rata Keaktifan Siswa Kelas Eksperimen II

Berdasarkan gambar 2 hasil observasi keaktifan siswa pada kelas eksperimen II menggunakan model pembelajaran kooperatif tipe Jigsaw mengalami peningkatan. Hal ini dapat dilihat dari perolehan persentase keaktifan siswa pada setiap pertemuan yaitu pada pertemuan pertama memperoleh persentase sebesar $70.92 \%$ dan pertemuan kedua memperoleh persentase sebesar $76.19 \%$ dengan rata-rata persentase sebesar $73.55 \%$. Hasil perolehan persentase antara pertemuan pertama dan kedua pada kelas eksperimen II dengan menggunakan model pembelajaran kooperatif tipe Jigsaw menunjukan adanya perbedaan yaitu memiliki kriteria aktif. Hal tersebut dapat dikatakan bahwa adanya pengaruh yang signifikan antara penggunaan model pembelajaran kooperatif tipe Jigsaw terhadap keaktifan siswa. Penelitian terdahulu terkait penggunaan model pembelajaran kooperatif tipe Jigsaw (Eva, 2018) menunjukkan bahwa hasil penelitian dengan menggunakan model pembelajaran kooperatif tipe Jigsaw berpengaruh terhadap keaktifan siswa dengan rata-rata keaktifan kelas ekperimen $71,60 \%$, dan kelas kontrol $66,40 \%$ dengan nilai dengan signifikasi 0,001 , dimana nilai sig $<0,05$.

c. Pengaruh Penerapan Model Pembelajaran Kooperatif tipe Numbered Head Together (NHT)Terhadap Hasil Belajar Kognitif Siswa

Hasil belajar kognitif siswa diperoleh dari hasil pretest dan posttest. Berdasarkan hasil pretest pada kelas eksperimen I diperoleh rentangan nilai 20-60 dengan rata-rata 37,30, sedangkan hasil posttest pada kelas eksperimen I diperoleh rentangan nilai 55-90 dengan ratarata 74,80. Gambaran perbedaan data hasil pretest dan posttest pada kelas eksperimen I terdapat pada gambar

3. 


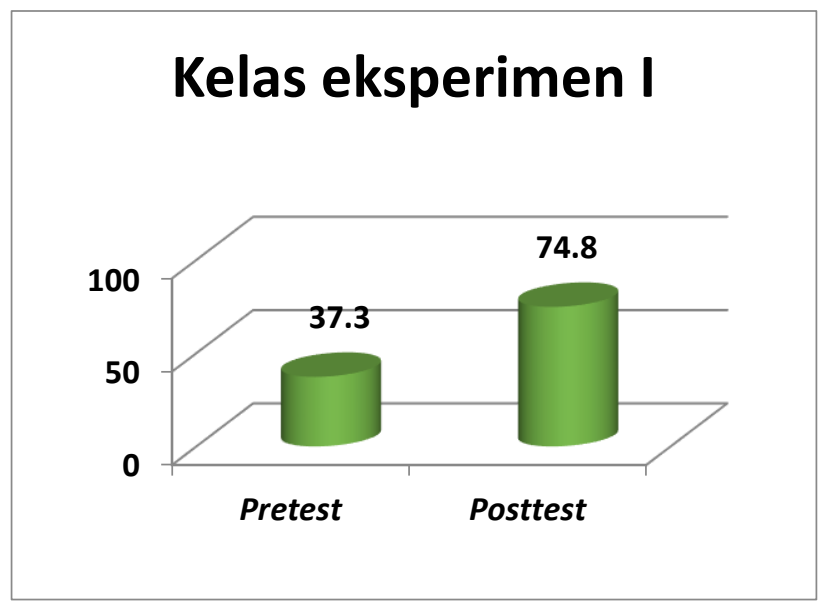

Gambar 3. Rata-rata Hasil Belajar Kognitif Siswa Kelas Eksperimen I

Berdasarkan gambar 3 menunjukan bahwa adanya perbedaan rata-rata antara pretest dan posttest pada kelas eksperimen I dengan menggunakan model pembelajaran kooperatif tipe NHT. Rata-rata nilai pretest kelas

eksperimen I sebesar 37,30 dan posttest sebesar 74.80. Hal ini menunjukan bahwa kemampuan awal dan akhir siswa kelas eksperimen Imengalami peningkatan. Hasil yang diperoleh dari nilai pretest dan posttest pada kelas eksperimen I telah membuktikan bahwa model pembelajaran kooperatif tipe NHT memberikan dampak positif terhadap peningkatan hasil belajar kognitif siswa. Kondisi tersebut dibuktikan dengan hasil analisis uji hipotesis pada model NHT. Hasil analisis menunjukan bahwa adanya pengaruh yang signifikan pada model pembelajaran kooperatif tipe NHT terhadap hasil belajar kognitif siswa.

Penggunaan model pembelajaran kooperatif tipe NHT pada kelas X SMA Negeri 2 maumere berpengaruh terhadap hasil kognitif siswa. Hasil tersebut didukung oleh penelitian terdahulu (Susanti, 2015) yang menyatakan bahwa penerapan model pembelajaran NHT berpengaruh terhadap peningkatan hasil belajar matematika siswa kelas VIII di MTs Muhammadiyah 2 Palembang. Hal ini dapat dibuktikan dengan hasil yang diperoleh dari nilai rata-rata posttest. Pernyataan tersebut juga dibuktikan oleh Sinulingga dan Batubara (2014) yang menyatakan bahwa terdapat pengaruh nyata pada pemberian model pemebelajaran NHT terhadap nilai hasil belajar kognitif siswa kelas VIII semester II SMP Swasta Taman Harapan Medan. Kondisi ini dapat diartikan bahwa model pembelajaran kooperatif tipe NHT merupakan model pembelajaran yang dapat meningkatkan hasil belajar siswa, karena sebagian besar siswa memperoleh nilai diatas rata-rata. Kurniasih (2017), menyatakan bahwa salah satu kelebihan model pembelajaran kooperatif tipe NHT adalah dapat meningkatkan prestasi belajar siswa.

d. Pengaruh Penerapan Model Pembelajaran Kooperatif tipe Jigsaw Terhadap Hasil Belajar Kognitif Siswa

Hasil belajar kognitif siswa diperoleh dari hasil pretest dan posttest. Berdasarkan hasil pretest pada kelas eksperimen II diperoleh rentangan nilai 10-55 dengan rata-rata 38,46, sedangkan hasil posttest pada kelas eksperimen II diperoleh rentangan nilai 50-80 dengan ratarata 65,96. Gambaran perbedaan data hasil 


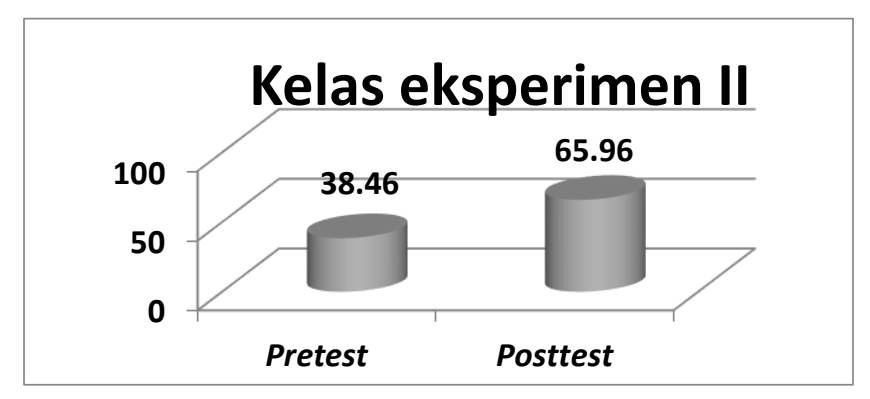

\section{Gambar 4 Rata-rata Hasil Belajar Kognitif SiswavKelas Eksperimen II}

Berdasarkan gambar 4.4 menunjukan bahwa adanya perbedaan rata-rata antara pretestdan posttest pada kelas eksperimen I dengan menggunakan model pembelajaran kooperatif tipe Jigsaw. Rata-rata nilai pretest kelas eksperimen II sebesar 38.46 dan posttest sebesar 65.96. Hal ini menunjukan bahwa kemampuan awal dan akhir siswa kelas eksperimen II mengalami peningkatan. Hasil yang diperoleh dari nilai pretest dan posttest pada kelas eksperimen II telah membuktikan bahwa model pembelajaran kooperatif tipe Jigsaw memberikan dampak positif terhadap peningkatan hasil belajar kognitif siswa. Kondisi tersebut dibuktikan dengan hasil analisis uji hipotesis pada model Jigsaw. Hasil analisis menunjukan bahwa adanya pengaruh yang signifikan pada model pembelajaran kooperatif tipe Jigsaw terhadap hasil belajar kognitif siswa.

\section{PENUTUP}

\section{Simpulan}

Berdasarkan hasil penelitian pada siswa kelas X SMA Negeri 2 Maumere dengan materi Keanekaragaman Hayati yang telah peneliti laksanakan dalam dua kali pertemuan, maka dapat ditarik kesimpulan bahwa penerapan model pembelajaran
Penerapan model pembelajaran kooperatif tipe Jigsaw pada kelas X SMA Negeri 2 Maumere berpengaruh terhadap hasil belajar kognitif siswa dan memiliki kriteria baik. Hasil penelitian Kartika, (2018) menyatakan bahwa penerapan model pembelajaran kooperatif tipe Jigsaw berpengaruh terhadap keaktifan dan hasil belajar siswa kelas XI IIS SMA Negeri 1 Bangsal Mojokerto. Sejalan dengan penelitian yang dilakukan oleh Juwaeriah (2017), bahwa hasil belajar kognitif dengan menggunakan model Jigsaw mengalami peningkatan karena model pembelajaran Jigsaw memiliki keunggulan yaitu siswa lebih aktif dalam berbicara, berpendapat, dan siswa diberikan kesempatan untuk berdiskusi serta semenjelaskan materi pada masing-masing kelompok. kooperatif tipe Numbered Head Together (NHT) dan Jigsaw berpengaruh terhadap keaktifan dan hasil belajar kognitif siswa pada materi keanekaragaman hayati kelasX SMA Negeri 2 Maumere. 


\section{Daftar Pustaka}

Eva, K, W. 2018. Pengaruh Model Pembelajaran Kooperatif Tipe Jigsaw II Terhadap Keaktifan dan Hasil Belajar Siswa Kelas XI IIS SMA Negeri 1 Bangsal Mojokerto. JUPE. Vol. 6 (2) : 42-47

Juwaeriah S, Muhyani, \& Ikhtino G. 2017. Pengaruh Penggunaan Model Jigsaw Terhadap Hasil Belajar Kognitif Siswa Pada Tema Udara Bersih Bagi Kesehatan. Jurnal Pendidikan Dasar Perkhasa. Vol. $6(1): 55-69$

Kartika, E, W. 2018. Pengaruh Model Pembelajaran Kooperatif Tipe Jigsaw II Terhadap Keaktifan dan Hasil Belajar Siswa Kelas XI IIS SMA Negeri 1 Bangsal Mojokerto. JUPE. Vol. 6 (2): $42-47$

Kurniasih. 2017. Pengaruh Pembelajaran Numbered Head Together dan Talking Stick Terhadap Hasil Belajar IPS di SMA Katolik ST Thomas Aquino. Jurnal Online STKIP PGRI Tulungagung. Vol. $1(2): 15-35$

Lie. 2002. Peningkatan Keaktifan Belajar Siswa dengan Menerapkan Strategi Team Games Tournament (TGT) pada Mata Pelajaran Matematika Kelas V SD N 4 Virgo Maria Ambarawa. Skripsi. Universitas Kristen Satya Wacana. Semarang.

Lufri. 2009. Pengaruh Penerapan Model Pembelajaran Make A Match Terhadap Hasil Belajar Peserta Didik Lintas Minat Tentang Materi Sistem Reproduksi Pada Manusia Kelas XI IPS. Bioeducation Journal. Vol. 3. (1) : 2715-4866

Marning \& Lucking. 1991. Pengaruh Model Pembelajaran Kooperatif Tipe Jigsaw Terhadap Motivasi Belajar dan Hasil Belajar IPS Siswa Kelas V Sekolah Dasar Gugus IV Jimbaran, Kuta Selatan. EJournal Program Pascasarjana. Vol. 4 (05) : 1-10

Mulyasa. 2002. Upaya Peningkatan Keaktifan Siswa Melalui Pembelajaran Berdasarkan Gaya Belajar Di SMK Negeri 1 Saptosari. Jurnal Electronics, Informatics, and Vocational Education (ELINVO).Vol. 1 (2) : 128-139

Rahayu. 2018. Analisis Model Pembelajaran Number Head Together Dalam Meningkatkan Keaktifan Siswa. Jurnal Pendidikan Administrasi Perkantoran (JPAP). Vol. 9 (1) : 154-168

Rauf, A., Hala, Y, \& Taiyeb, M, A. 2017. Pengaruh Pembelajaran Kooperatif Tipe Numbered Head Together (NHT) Terhadap Motivasi dan Hasil Belajar IPA Biologi Siswa Kelas VII SMP Negeri 1 Watampone. Jurnal Nalar Pendidikan. Vol. 5 (1) : 46-54

Rusman. 2008.Pembelajaran Fisika Menggunakan Model Jigsaw dan GI (Group Investigation) Ditinjau dari Kreativitas dan Sikap Ilmiah Belajar Siswa. Jurnal Inkuiri. Vol. 5 (3): 40-48

Sari, J, Bahar, A. \& Handayani, D. 2017. Studi Komparasi antara Model Pembelajaran Discovery Learning dan Group Investigation Terhadap Hasil Belajar Kimia Siswa. Jurnal Pendidikan Dan Ilmu Kimia. Vol. 1 (1) : 60-65. 
Silalahi, R. R. \& Hasruddin. 2016. Perbandingan Model Pembelajaran Kooperatif Tipe NHT dengan STAD Terhadap Hasil Belajar Siswa pada Materi Sistem Pencernaan Manusia. Jurnal Pelita Pendidikan. Vol. 4 (2) : 053-060

Sinulingga \& Batubara. 2014. Efektivitas Model Pembelajaran Problem Based Learningdan Number Head Together Terhadap Keterampilan Proses Sains dan Hasil Belajar Siswa Kelas VII SMP Santa Maria Maumere. Spizaetus : Jurnal Biologi dan Pendidikan Biologi. Vol. 1 (2) : 40-52

Sugiyono. 2010. Metode Penelitian Pendidikan : Pendekatan Kuantitatif, Kualitatif, dan R\&D. Alfabeta Bandung

Susanti, I. 2015. Pengaruh Model Pembelajaran Kooperatif Tipe Number Head Together (NHT) Terhadap Hasil Belajar Matematika Siswa Kelas VIII Di Mts Muhamadiyah 2 Palembang. Skripsi. Fakultas Tarbiyah Dan Keguruan Universitas Islam Negeri Raden Fatah Palembang

Utami, R., Sinaga, E., \& Dongoran, H. 2017. Perbedaan Hasil Belajar dan Aktivitas Siswa Menggunakan Model Pembelajaran Kooperatif Tipe Jigsaw dengan NHT pada Materi Sistem Pernapasan Manusia. Jurnal Pelita Pendidikan. Vol. 6 (3) : 156-166. 